\title{
THE BAND OF ABDUL QAHHAR MUDZAKKAR Biographical Sketch of Rebelious Leaders of Islamic State- Indonesian Islamic Army (DI/TII) of Sulawesi
}

\author{
Muhammad Hasbi \\ STAIN Watampone, Indonesia| muh_hasbi21@yahoo.co.id
}

\begin{abstract}
The rebellious movement of Islamic StateIndonesian Islamic Army (DI/TII) began from dissatisfaction towards the secular state of newly independent Indonesia. Abd. Qahhar Mudzakkar, the leader of DI/TII in Sulawesi and his followers revolted against the government, and subsequently formed their own Islamic government. Since Qahhar graduated from Muhammadiyah school, his theological basis in his cause to establishing an Islamc state is very prevalent. He believed that his Islamic state is to uphold the truth and to defend the religion of Allah. Thus whoever opposed his DI/TII movement would be considered infidel simply because of favoring or supporting the Indonesian government they considered secular and communist. His followers and supporters were preachers and clerics, who helped Qahhar by carrying out specific functions and positions in his Islamic state. In addition, those people played an important role in getting recognition and acceptance of Sulawesi muslim society for Islamic state campaign launched by Abdul Qahhar Mudzakkar. Without their involvement, DI/TII would never had been so popular among muslim community in Sulawesi.
\end{abstract}

Keywords: DI/TII, Abd. Qahhar Mudzakkar, Sulawesi, Islamic state/darul Islam.

\section{Introduction}

Abd. Qahhar Mudzakkar fought for Indonesian independence in the military. He was one of the guards for Soekarno in 1945. in 1946, the Indonesian Army Chief of Staff, Sudirman, ordered him to return to Sulawesi with the mission of creating an embryo entity for 
Indonesian Military. Later, he led a voluntary guerilla group in resisting the returning Dutch in Sulawesi. His resistance supplemented the national army in driving out the Dutch. When the Dutch acknowledged the independence of Indonesia in 1949, many of Dutch armed militias, mainly KNIL, were incorporated into Indonesian military as part of negotiation package between Indonesian government and the Dutch. ${ }^{1}$

The guerilla forces, however, did not enjoy the similar treatment which they wanted to. After the war with the Dutch ended the Indonesian military authority wanted the guerilla groups to demobilize and returned to civilian lives. However, these guerilla group wished their incorporation into Indonesian military. Series of negotiation between the guerilla forces and the military only resulted in inclusion of minimal number of guerilla groups into military. Abdul Qahhar Mudzakkar and his group, dissatisfied with the military offer, decided to wage another guerilla war. This time, war against central government and the military. That happen in $1950 .{ }^{2}$

At the same time, the event unfolded in Java when Kartosuwirjo declared his Islamic state of Indonesia. He wrote a letter to Abdul Qahhar Mudzakkar asking him to join forces and promised him a high position in the Indonesian Islamic Army. Initially declined the offer, finally he agreed to join DI/TII in 1952 after there was disunity among guerilla groups in Sulawesi and they joined TNI (the military). Abdul Qahhar Mudzakkar himself and his guerilla group was pushed deeper into the forest by the offensive military campaign. He openly declared his affiliation to DI/TII in the following year of 1953. Kartosuwirjo appointed Abdul Qahhar Mudzakkar as the Army Chief Division IV of Indonesian Islamic Army. This division was also called as Hasanudin Division. After successful DI/TII campaign in the following two years, Kartosuwirjo appointed Abdul Qahhar to become the first Deputy for Minister of Defense in the Indonesian Islamic Army in 1955. ${ }^{3}$

\footnotetext{
${ }^{1}$ Cornelis Van Dijk, Darul Islam: Sebuah Pemberontakan (Jakarta: Pustaka Utama Grafiti, 1987), pp. 175-182.

2 Anhar Gonggong, Abdul Qabhar Mudzakekar: Dari Patriot bingga Pemberontak (Yogyakarta: Ombak, 2004).

${ }^{3}$ Van Dijk, Darul Islam, pp. 143-150, and pp. 175-182.
} 
The success of Abdul Qahhar Mudzakkar in gaining popular supports as well as in containing the military campaign in Sulawesi could not be separated from the service of several prominent religious leaders who joined him. Abdul Qahhar Mudzakkar knew his limitation as he often criticized feudal system and aristocracy in Sulawesi. ${ }^{4} \mathrm{He}$ himself could not win the war. Thus, he recruited many local religious leaders for this purpose.

One of the strategies to win heart and mind of muslim community in the region was by approaching several local religious leaders who had many followers. In Sulawesi's context, the most referred muslim cleric is called as Anre Gurutta. This Anre Gurutta is the highest informal position of muslim cleric in Sulawesi. Muslim community in the region considered him as mufti to whom they asked questions about Islamic issue. Anre Gurutta is also the highest spiritual authority to whom muslim community in the region hope for his guidance and supplication. Considering this position, an Anre Gurutta has many followers who would obey anything Anre Gurutta said and ordered. ${ }^{5}$ Similar to the influence of Anre Gurutta is murshid (spiritual teacher) of tariqah (sufi order). In Sulawesi, the most pupolar tariqah is Khalwatiyyah Samman. Therefore, Abdul Qahhar Mudzakkar tried with all available means to recruit an Anre Gurutta, mursyid, and other local religious leaders.

In addition to bolstering the legitimacy of DI/TII, Abdul Qahhar Mudzakkar also used the clerics and preachers to fill several civil and religious positions within his Islamic state arrangement. His Islamic state had proper civil and military apparatus. Its military apparatus is called Tentara Islam Indonesia or Indonesian Islamic Army, like its counterpart in Java. Their main stronghold is South and Southeast Sulawesi. ${ }^{6}$

The Islamic state of Abdul Qahhar Mudzakkar took place in his hideout in the forest. It had citizen that lived in well-arranged districts. The state structure that formed was starting from the central

\footnotetext{
${ }^{4}$ Michael Buehler, "Elite Competition and Changing State-society Relations: Shari'a Policy Making in Indonesia," in Michele Ford and Tom Pepinsky (eds), Beyond Oligarchy: Wealth, Power, and Contemporary Indonesian Politics (Ithaca: Cornell Southeast Asia Program Publications, 2014), p. 167.

5 Syamsuddin Arief, "Dinamika Jaringan Intektual Pesantren di Sulawesi Selatan," in Lentera Pendidikan, Vol 11:2 (December 2008), pp. 167-181.

${ }^{6}$ Van Dijk, Darul Islam, p. 147.
} 
level, districts, until the lowest level. The state had ministers and high officials, both at the central level and regions. Schools ranging from elementary to College levels were founded. Although the administration department had been deemed permanent, but facilities such as building and a number of other supporting devices were still in the emergency, including government offices and school buildings. The college founded during his reign was called Islamic College of AlQashas led by KH. Abdurrahman Ambol Dalle.

In the forest, DI/TII of Abdul Qahhar Mudzakkar did not only open schools to provide educational services and knowledge (public and religious affairs) to society, but reading Alqur'an was also obligated both in household environment and social environment even in army barracks. For this purpose of providing religious policy recommendation, instructions, and other related matters, Abdul Qahhar Mudzakkar recruited many prominent preachers and clerics. The following section will be devoted to provide a short biography of Abdul Qahhar Mudzakkar and some influential religious leaders recruited voluntarily or forcibly by Abdul Qahhar Mudzakkar.

\section{Brief History of Abdul Qahhar Mudzakkar}

Lanipa is one of remote villages in Palopo District of South Sulawesi province, where Ladomeng (given name of Abd. Qahhar Mudzakkar) was born and grew until the age of childhood. After graduating at elementary school in that village in 1934, his parents (Malinrang and Kaesang) wanted him to continue his study in Palopo. So, he went to junior high school, made him to leave parents in village for some years. Luckily, His father Malinrang, who was a wealthy person, had a relative in Palopo where Qahhar could stay.

Abdul Qahhar studied his junior high school in Standard School of Muhammadiyah that was not far from his residence. Apparently, the schools affiliated to Islamic organization, Muhammadiyah. At that time his name, Ladomeng, changed to Kahar (later then Qahhar). ${ }^{7}$ As a new student, he tried to fit in with the new environment, to make the

\footnotetext{
7 Ladomeng the name given by his parents, the teachers in Standard School of Muhammadiyah Palopo changed the name to Kahhar, because the feared to be the subject of ridicule from his friends. When he continued his study at Kweek School (Mu'allimin) Muhammadiyah Solo Central Java he asked permission from his teacher, Abd. Qahhar Mudzakkar use similar name but different in the last name. The teacher had no objection. He then used Abd. Qahhar Mudzakkar. The only different was "Mudzakkir" and "Mudzakkar."
} 
acquaintance with other students, including the senior students. He could adjust himself easily with his new environment.

In his new school, Qahhar sometimes showed the attitude differrent from his friends. He used to argued his teachers fiercely for something he disagreed and tried to defend his stand for what he believed was true. So that's way, in the class Qahhar was frequently given punishment by his teachers by leaving the classroom during the lessons.

The Standard School of Muhammadiyah where Qahhar studied had a library room with various kinds of books, including books of science and religion. It was quite luxury for a small school in small area and in a very difficult time for having such a good collection of books. If he was expelled from the class room for boldness, Qahhar went to the school library to read books. He did not want to let his relatives know that he left the school before time because of punishment he received. Reading a number of books in library was a predilection for Qahhar, because through books he could develop his knowledge, particularly on religion and even matters of politics. Reading more books and understanding more problems allowed him to be able to overcome any problems. Therefore, he did not hesitate to refute the explanation of teachers and give his opinion that he thought more reasonable and argumentative, although it would offend the teachers.

Qahhar believed that it was fine for him to leaving the class punished as long as he could express his opinion based on his readings. Moreover, he could get the opportunity to read more books on a variety of his favorite subjects. Knowledge and insights that he had got from reading in library were assets for Qahhar to continue study to another area that he was considerable to meet his thirst for knowledge. Moreover, Standard School of Muhammadiyah in Palopo was not supposed to be able to satisfy his demand for knowledge. One reason was that he was sometimes quite difficult to understand the teachers' explanations. ${ }^{8}$

Before graduating, Qahhar got information from the administrator of Standard School of Muhammadiyah in Palopo about Kweek School (Mu'allimin) Muhammadiyah Solo, Central Java. Therefore, after finishing his study at Standard School of Muhammadiyah Palopo in 1934, Qahhar asked for permission from his parents to continue his

${ }^{8}$ Gonggong, Abdul Qabhar Mudzakekar, pp. 26-35 
study in Central Java. Malinrang, Qahhar's father, permitted him to go to Central Java in continuing his study in that school, Kweek School Muhammadiyah Solo.

Qahhar did not face any difficulties to be accepted in Kweek School (Mu'allimin) of Muhammadiyah Solo, because this school was prepared to accept the graduations of the lower level school such as Standard School of Muhammadiyah scattering in various areas and regions across Indonesia. According to the rules in the Organization of $\mathrm{Mu}$ hammadiyah at that time, students graduated from Standard School of Muhammadiyah scattering in various areas that would be naturally accepted at Kweek School (Mu'allimin) of Muhammadiyah without examination. Thus, at the same year (1938), Qahhar was registered as a student at the educational institution and immediately allowed to follow the lessons.

Similarly with the prior school in Palopo where Qahhar studied knowledge, Kweek School (Mu'allimin) Muhammadiyah Solo served a variety of subject matter, both general subjects such such as history, mathematics, Indonesian language; religion of Islam such as Figh (Islamic jurisprudence), Akhlaq (ethics), Aqidah (theology), history of Islam and other subjects. The school, too, had good library containing books of variety subjects.

His desire for studying many books was getting stronger because collection of books in the library was sufficiently provided. Qahhar could then choose the books that interested him to read in developing his knowledge. His predilection to study many books about history of nations, Islamic movement, and politics improved, he even increased that enthusiasm when received at this school. The books that he studied inspired him to fast plunging into political struggle.

In addition to lessons and library, Kweek School (Mu'allimin) of Muhammadiyah Solo had qualified teachers in different disciplines. It was one reason that students from various places came to this school to continuing their study. One of the credited teachers of the school was Prof. Dr. Abdul Qahhar Mudzakkir. Qahhar had got much valuable knowledge from him and he admired and idolized him very much.

Qahhar quickly realized his desire and expectation in action and revolution. He could not sit back if something planned was not realized immediately. He felt having sufficient knowledge for further actions. Therefore, Qahhar thought that it was not necessary to 
complete his study at the school, if he could move forward to realise his goals and desires as soon as possible, especially his goal and desire to realize the knowledge that he had gained during schooling. One desire or expectation need to be immediately realized was his involvement in a resistance organization. Since through the organization, he was able to gather a lot of people as the first step to realize his plan.

Thus, although Qahhar initially came to Solo with the intention of continuing study, but he was affected more by the environmental conditions. In the decade of 1930s, the educated mass of Indigenous Indonesia had started their resistance and opposition towards the Dutch colonial rule. 9 Therefore, studying was not longer the only objective of Qahhar struggle in Solo. Instead, he used the institution of Kweek School (Mu'allimin) of Muhammadiyah Solo as an intermediate goal to reach a real goal.

After one year in Kweek School (Mu'allimin) of Muhammadiyah, Qahhar could understand the situation and conditions throughout Solo. He often wandered around the city and visited certain places to meet with community leaders and the local people. Making a visit to get acquainted with certain people is a reasonable thing. Qahhar did not distinguish between people who were close to him, regardless their social, economic, cultural background and even their tribe and language. Indeed since the beginning, Qahhar was known to have congenial personality and easily acquainted with everyone.

Solo during the time was one of cultural and educational cities. It was a meeting point of people coming from various regions in this archipelago. Therefore, Qahhar met and got acquaintance with many people from Sulawesi, Sumatra, Kalimantan, Ambon, and other regions. As Solo became a meeting point of people from different areas of Indonesia, Qahhar viewed it a momentum and great opportunity to get acquainted, exchange thoughts and experiences, and built a relationship in a variety of things that could provide mutual benefit. Thus, at the end he did not finished his study in this Kweek School of Muhammadiyah. Instead, he married with local girl and returned to his hometown, Palopo. ${ }^{10}$

\footnotetext{
${ }_{9}^{9}$ Deliar Noer, Gerakan Modern Islam di Indonesia 1900-1942 (Jakarta: LP3ES, 1990).

${ }^{10}$ Hamdan Juhannis, The Struggle for Formalist Islam in South Sulawesi: From Darul Islam (DI) to Komite Persiapan Penegakan Syariat Islam (KPPSI) (Unpublished Dissertation, Canberra Australian National University, 2006), pp. 32-53.
} 
He later involved in Muhammadiyah-affiliated youth organization called Hizb al Watan in Luwu, South Sulawesi. His resentment towards the existing unjust local social structure grew as he began to criticize feudalism and aristocracy. He and his colleagues from Hiz̧ al Watan had a new cause of fighting against this structure. When Japanese opposition started in 1942, he worked of its information agency called Nippon Hodobu. He used his position to further attack the feudal lords which triggered reaction from them. At last, he was expelled from his hometown and forced to return to Solo, Central Java in 1943.

In Solo he opened a business and organized an independence movement by setting up Gerakan Pemuda Indonesia Sulawesi (GEPIS, Indonesian Youth Movement of Sulawesi) which was part of Angkatan Pemuda Indonesia (API, Indonesian Youth Movement). After Indonesia proclaimed independence I 1945, he became one of Soekarno's bodyguard. After leaving GEPIS, which later transformed into Kebaktian Rakyat Indonesia Sulawesi (KRIS, Devotion of the Indonesian People of Sulawesi) for internal conflict, albeit its success in forming several paramilitary units in Java, he formed Batalion Kesatuan Indonesia (BKI, Indonesian United Battalion). This battalion's successful service was its operation as President Soekarno's protection guard when he moved to Yogyakarta. In 1946, BKI transformed into Tentara Republik Indonesia Persiapan Sulawesi (TRIPES, Indonesian Republic Preparatory Army for Sulawesi). In doing so, Sudirman, the Commander in chief of Indonesian Army ordered him to return to Sulawesi in preparing the infiltration of Indonesian soldiers from Java to Sulawesi. ${ }^{11}$

After the mission, which was deemed successful, he suffered several disappointments when dealing with the Indonesian army as well with central government. The last straw was the refusal of the army to incorporate guerilla forces into Indonesian armed forces. Initially, he and his guerilla group was a mere illegal armed group with no ideological basis, but later joined DI/TII in 1952, declared this affiliation on since August 7, 1953. He was shot to death on February 4, 1965. ${ }^{12}$

\footnotetext{
${ }^{11}$ Ibid.

12 Wanua Tangke and Anwar Nasyaruddin, Sejarah Tertembaknya Kahar Muzakkar di Hutan (Makassar: Pustaka Refleksi, 2007), p. 46; Aswar Hasan, The Chief of KPID South Sulawesi, Interview, June 2014 in Makassar.
} 


\section{The Ulama of Abdul Qahhar Mudzakkar}

Abdul Qahhar Mudzakkar recruited many ulama (muslim clerics) either voluntarily or forcibly. Some came and gave support to his authority of their own accord, and some were abducted or taken forcibly to forest that no other option for them but joining the rebellion. The clerics who joined voluntarily after being asked his approval by Qahhar was KH. Ma'shum from Java. He was Qahhar's teacher in Java. Other cleric, K.H. Abdurrahman Ambo Dalle, was abducted by Qahhar. He was a charismatic cleric of South Sulawesi at the time. He and several other clerics were arrested by guerrilla forces of DI/TII and later forced to support the rebellion. ${ }^{13}$ As mentioned before, the recruitment was important for bolstering the authority of DI/TII, giving advice and guidance in religious matters, and filling religious positions in Islamic state of DI/TII. In addition, Qahhar felt less competent in field of religion, so he recruited Muslim clerics to fill the gap although some of them were reluctant in joining DI/TII. Briefly, the ulama embraced by Qahhar in his government of DI/TII, will be mentioned below.

\section{Anre Gurutta Abdurrahman Ambo Dalle}

KH. Abdurrahman Ambo Dalle was known as a charismatic preacher, he lived in Pare-Pare of South Sulawesi. Muslim community in Selawesi respected him as a pious and knowledgeable Muslim scholar. In 1947, he and other prominent traditional muslim leaders in Sulawesi founded of the Institute of education and Da'wah well known as DDI (Darud Da'wah wal Irsyad). The Institute was an organization of traditional muslim in Suoth Sulawesi that had original goal of conserving the Islamic teaching ala abl al-sunnah wa al-jama'ah. ${ }^{14}$

As a Muslim scholar, he had long studied in Mecca and even taught in the holy city. After returning to motherland, many students from various regions came to study knowledge of Islam under his tutelage. Those who came to him, not only the students living around the residence, but rather from different areas outside of Sulawesi, such as Kalimantan, Java (Madura), and Sumatra. Once the students gradua-

\footnotetext{
13 Gonggong, Abdul Qabhar Mudzakkar, pp. 232-33.

14 On this note, Darud Da'wah wal Irsyad is similar to Nahdlatul Ulama in Java. Please read Choirul Anam, Pertumbuban dan Perkembangan Nabdlatul Ulama (Sala: Jatayu, 1985) for account about Nahdlatul Ulama.
} 
ted from their study with him, they returned home and established branches of DDI in their respective hometown.

The story behind his support to DI/TII was quite intriguing. Instead of joining voluntarily, he was abducted in Maros by DI/TII troops in his way to Makasar in 1955. The motive behind this abduction was to persuade KH. Abdurrahman Ambo Dalle to join DI/TII in one way or another. After Abdul Qahhar Mudzakkar declared his rebellion as part of Kartosuwirjo's DI/TII, he planned to apply shari'a. Therefore, he needed a charismatic man with vast knowledge in Islam to fill position of Ulama assembly. Anre gurutta Abdurrahman Ambo Dalle fitted that description perfectly. In addition, he had many colleagues and followers. His joining to DI/TII would attract popular support to the rebellion.

After being arrested by Nurdin Pisof troops of DI/TII under the command of Bahar Mattilioe, he was taken to a forest in order to join and help the Government of DI/TII. Though having a feeling of being compelled and left without option, he then agreed to join DI/TII as the grand mufti. He also taught and preached people under the authority of the Government of DI/TII.

The appointment of Ag. Abdurrahman Ambo Dalle as grand mufti within DI/TII government precipitated other clerics affiliated to him to join the rebellion. The main reason for the band wagon is the conviction of the followers of Ag. Abdurrahman Ambo Dalle that what he did, including his decision to accept DI/TII offer, was religiously based. After all, what DI/TII fought for was the creation of an Islamic state which echoed loudly in the teaching of Islam. As one of leading figures of Dewan Da'wah wal Irsyad, the decision to join DI/TII, albeit reluctantly, had domino effect that Abdul Qahhar Mudzakkar originally intended. Therefore, there was no reason for not following him. Some notable clerics were KH. Abdul Muin Jusuf, (a Qadi [judge in Islamic court] of Sidenreng Rappang), KH. Junaid Sulaiman (Qadi of Bone), KH. Abdurrahman Matammeng (Qadi of West Bone). In addition to them, several preachers also joined DI/TII of Abdul Qahhar Mudzakkar, such as KH. Ahmad Marzuki Hasan (Chairman of Muhammadiyah Bulukumba Sinjai), KH. Ma'shum (teacher of Qahhar in Solo), and KH.Sulaeman from East Java. ${ }^{15}$

15 M. Yusrie Abady, Konsepsi dan Praksis Politik Islam Abdul Qabhar Mudzakkar (Unpublished Dissertation, Postgraduate Program UIN Syarif Hidayatullah, Jakarta, 2011), p. 120. 
Thus, in the reign of DI/TII, it was known that many clerics of DDI were assumed affiliating and supporting the Government of DI/TII. But they actually followed their beloved religious leaders. Being gathering with the people, troops, and officials of DI/TII, the followers of Ag. Abdurrahman Ambo Dalle also participated and engaged in several of programs of DI/TII.

After joining the government of DI/TII, Ag. Abdurrahman Ambo Dalle got many duties and mandates, such as teaching at formal school. Outside the school, he also served people who want to learn Islamin special session, such as tutorial teaching ("sorogan" in pesantren term). ${ }^{16}$ Among those who came to him for tutorial session were sons of Abd. Qahhar named Hasan Mudzakkar and Guril. ${ }^{17}$

Ag. Abdurrahman Ambo Dalle also instigated the establishment of an Islamic College for DI/TII called College of Al-Qasas ${ }^{18}$. The College was located in Bajo district, South Palopo. He also founded an Islamic boarding school before in Soro village near Maroangin. The Islamic boarding school was founded in 1957, two years after he was brought in by a single battalion of guards of Abdul Qahhar Mudzakkar to the area. By the orders of Abdul Qahhar Mudzakkar Ag. Abdurrahman Ambo Dalle was moved to Luwu, Bajo district where College was established.

Ag. Abdurrahman Ambo Dalle also led the al-Qasas College and was assisted by a number of lecturers. Some Experts from abroad captured by DI/TII were also made use for teaching at the college such as, Dr. V.D. Watering (Netherlands), DR.Wahl (Germany), and Sibenus Treep (Netherlands). The three foreigners were initially arrested for entering the conflict area, but in the end they made covenant with DI/TII for teaching at Al-Qasas College at Headquarters of DI/TII. In addition, there was also a Protestant clergyman, H. Vers-

16 Teaching system of sorogan is that one is coming to the teacher or sermoner having with him certain holy book by expectation that the sermoner would guide him to understand the content of the holy book. While, the teaching system of bandongan is that some people under the guide of teachers or sermoner to learn the content of a holy book. Some of them bring the same holy book to be learned together under the guide a teacher or sermoner. See Muhammad Daud Ali and Habibah Daud Ali, Lembaga-lembaga Islam di Indonesia (Jakarta: Raja Grafindo Persada, 1995).

17 AG. KH. Ambo Dalle and DI/TII Kahar Muzakkar in www. Referensimakalah.com. Accessed on 5 July 2014.

18 See, Abd. Rahman Hamid, Qabhar Mudzakkar di Persimpangan Jalan (Makassar: Pustaka Refleksi, 2008), p. 44. 
teeden, who later converted to Islam and renamed Abdul Hakim. This convert also taught at the College. Wife of Qahhar, Corry Van Stenus, from also gave lecture. Military course was particularly given by Lieutenant-Colonel J.W.Gerungan, who later was appointed as Minister of Defense. ${ }^{19}$

Though the College was managed directly by the headquarter of DI/TII, it kept the status as an Islamic College under the leadership of Ag. Abdurrahman Ambo Dalle. Therefore, lecturers giving courses were experts in their field. Public courses were delivered by foreign experts and some other experts, while religious subjects (Islam) were taught by some of the clerics affiliated to DI/TII. During his joining with DI/TII, Ag. Abdurrahman Ambo Dalle was once given a mandate to occupy the position of Chairman of the Board, the Vice President of DI/TII in 1958, and Ministry of V Education. Outside of cabinet structure, his other duties were Rector of Islamic University of Al-Qasas, head of Islam boarding school, and grand mufti. ${ }^{20}$

Although Ag. Abdurrahman Ambo Dalle had already shown his willingness to cooperate with DI/TII, finally he had to swallow bitter fact that his service was no longer required by Abdul Qahhar Mudzakkar. After a dispute with Abdul Qahhar Mudzakkar about a religious doctrine, he was exiled to Lambae village, Kolaka in South East Sulawesi along with other clerics and people that favored him in the dispute such as, KH. Abdul Rahman Matemmeng, K.H. Ali Yusuf, and K.H. Hussein. This ended 8 year of collaboration between Abdul Qahhar Mudzakkar and Ag. Abdurrahman Ambo Dalle. In addition, several DI/TII military personnel affiliated with the Sunni clerics such as Captain Mensong (Commander of battalion VI in DI/TII), Captain Saleh (brother of Captain Mensong), and Captain Andi Batti (Deputy Commander of Battalion VI of DI/TII were also arrested. This event was we known by the term of penselonan (the disposal of prisoners from the domain of DI/TII). The exile was under the supervision of Lieutenant Colonel Jufri Tambora (the younger brother-in-law of

\footnotetext{
${ }^{19}$ See, Abady, Konsepsi dan Praksis Politik, p. 161.

20 The guidance of the book in bandongan is some of the people brought the guidance teacher or sermoner (Kiai) to learn certain book contents. Some of the people brought the same book and studied together any way under the guidance of a teacher or sermoner. See, Ali and Habibah Daud Ali, Lembaga-lembaga Islam, 1995.
} 
Qahhar), who was given the duty as Division Commander DI/TII of Southeast Sulawesi. ${ }^{21}$

The exile was grounded by Ag. Abdurrahman Ambo Dalle's different opinion from Qahhar and KH. Ma'shum about polygamy. KH. Abdurrahman Ambo Dalle believed, as it is traditional interpretation, that polygamy in Islam could be done with the maximum of four wives. Polygamy could be done by those who were able to treat equally the wives. If not, he is only allowed to have one wife, as stated in the Holy Qur'an Chapter 4 verse 3. At that time Abdul Qahhar Mudzakkar had four wives already. On the other hand, Abdul Qahhar Mudzakkar understood, supported by KH. Ma'shum, that polygamy was allowed up to nine wives. The difference in opinion about polygamy made Qahhar as a supreme leader of DI/TII felt that his authority was challenged. As a result, he exiled those who opposed his opinion.

\section{KH. Ma'shum}

KH. Ma'shum was one of Abdul Qahhar Mudzakkar teacher when he was studying in Solo, Central Java.22 Nothing else could be told about his biography except that Abdul Qahhar Mudzakkar invited him to support the rebellion in 1963. According to Anshoriy, his approach of Islamic jurisprudence close to the school of Dhahiri. ${ }^{23}$ This explains the background of his controversial opinion on permissibility of having 9 wives.

KH. Ma'shum and KH. Abdurrahman Ambo Dalle were different in the way of giving support to Qahhar. KH. Abdurrahman Ambo Dalle was indeed appointed to be the Chairman of fatwa council of DI/TII. However, he would stand for his opinion, which is based on his interpretation on Islamic doctrines, even if it appears contrary to the opinion of Abdul Qahhar Mudzakkar, the top leader of DI/TII.

\footnotetext{
${ }^{21}$ www.http://ifuljihad.blogspot.com/2009/02/kh-abd-rahman-ambo-dalle.html

22 It is certainly clear that this KH. Ma'shum is not the charismatic KH. Ma'shum of Lasem, Central Java. Considering the opinion concerning polygamy issue, it is difficult to believe that this KH. Ma'shum of Solo is the same person with KH. Ma'shum of Lasem. KH. Ma'shum of Lasem was known for his strong commitment to traditional Shafi'I school of law. Thus, he would never issue such controversial opinion. Moreover, the resource of DI/TII states that KH. Ma'shum came from Solo, not Lasem.

${ }^{23}$ Nasruddin Anshoriy, Anregurutta Ambo Dalle: Maha Guru dari Bumi Bugis (Yogyakarta: Tiara Wacana, 2009), pp. 97-103.
} 
Meanwhile, KH. Ma'shum would supported Mudzakkar's opinions even if they were contradictory to mainstream Islamic doctrines. Therefore, because there were views of Abdul Qahhar Mudzakkar that were contradictory to $\mathrm{H}$. Abdurrahman Ambo Dalle, Abdul Qahhar Mudzakkar invited KH. Ma'shum from Java to provide the opinions that suited his.

Because of that difference, KH. Abdurrahman Ambo Dalle forfeited his support to DI/TII religious stances, and his position as Chairman of Fatwa Council was replaced by KH. Ma'shum. This replacement created a considerable decrease of popular support to DI/TII rebellion because a number of clerics and preachers affiliated to KH. Abdurrahman Ambo Dalle also withdrew their support to DI/TII.

\section{KH. Ahmad Marzuki Hasan}

Kyai Ahmad Marzuki Hasan is a modernist Muslim theologian known as a strong, assertive personal, warrior, and preacher. Kyai Marzuki was born on January 31st, 1917 in Sinjai, South Sulawesi. His father, named Kyai Hasan, was a Qadhi in East Sinjai, while his mother is Syarifah Aminah. Marzuki studied elementray school of Muhammadiyah and later studied in Pesantren As'adiyah Sengkang Wajo.

He continued further study at Datumuseng College in Makassar city. In addition, he also studied the Holy Qur'an to Prof. Dervish Zakaria (a teacher in Datumuseng College from West Sumatra) in the same city. ${ }^{24} \mathrm{KH}$. Ahmad Marzuki Hasan also learned theology to KH. Muhammad As'ad who was known as a traditional Sunni theologian.

In the course of his knowledge career, he was associated with the reformist theology of Muhammadiyah scholars and examined the books on muslim reform. As a result, he tended to think in Islamic reform. He became active in Masyumi and Muhammadiyah. He joined Muhammadiyah because he believed that Muhammadiyah interpreted Islam correctly and he considered Muhammadiyah as the most suitable means in promoting Islam at that time.

After he finished his study, he went home in Sinjay to teach and preach. His stern and non-compromising attitude on Islam made him

24 Yanuardi Syukur, KH. Ahmad Marzuki Hasan: Potret Pejuang Syari'at Islam, in https://konstruksipelangi.wordpress.com/2012/06/06/kh-ahmad-marzuki-hasan-potret-pejuang-syariat-islam/ accessed on 12 of August 2014 
accused as member of extremist group. He went Jakarta to join Masyumi. He was quite close to Muhammad Natsir, the Masyumi leader at that time. He worked in Masyumi office in Jakarta until 1953 when Abdul Qahhar Mudzakkar declared his DI/TII in Sulawesi. After its declaration he contacted KH. Marzuki Hasan in Jakarta to join the rebellion. After asking permission to Muhammad Natsir for joining DI/TII, KH. Marzuki Hasan agreed to join Abdul Qahhar Mudzakkar. The main consideration was that DI/TII would be able to serve Islam better than in the available government at the time. he did not mind of living in the forest for doing so. ${ }^{25}$

Motivation to fight for Islam prompted KH. Marzuki Hasan to join Qahhar in establishing the Islamic State in Sulawesi. He argued that education and missionary endeavor of Islam in the state of Islam should be conducted smoothly, safely, and effectively. This was his understanding of Muhammadiyah mission as well and was in tune with the state ideology of DI/TII. It was the reason that in Abdul Qahhar Mudzakkar's DI/TII, KH. Marzuki Hasan was appointed to occupy the position as a Minister of Information, and he was one of the people who gave signature on Makalua Charter, Constitution of DI/TII. ${ }^{26}$ As a theologian closer to Qahhar and occupied an important position in Government, he had at least given influences theologically to the Government of DI/TII. That influences were reflected in Makalua Charter and the course of Government.

KH. Marzuki Hasan joined DI/TII for until its demise in 1965. The role KH. Marzuki Hasan in DI/TII was so important. Abdul Qahhar Mudzakkar once said that he fought for Islam physically, and the spirit of the fight rested in KH. Marzuki Hasan. During his decade with DI/TII, he founded a university, wrote several monographs on Islam and continued his ritual as a pious Muslim. After the rebellion was permanently suppressed by the government, he founded a boarding school of Darul Istiqamah in 1970 and taught in that school. He also continued his da'wah through Muhammadiyah until his death. ${ }^{27}$

\footnotetext{
25 Ibid.

${ }^{26}$ Names gave signature on Makalua Charter at 1 Rajab 1376 H/1957 CE. Ahmad Marzuki Hasan is the second who positioned on Minister of Information of RII. Source of Data: Documentation of Organizational Structure and Regulation of RII DI/TII KPK Information of RII in 1957.

${ }^{27}$ Syukur, KH. Ahmad Marzuki Hasan.
} 


\section{Syekh Abdus Shamad, Syekh Mursyid of Khalwatiyah Tariqah}

According to Syekh Muhammad Ali bin Jaffar, ${ }^{28}$ one of Murshid Tarekat Khalwatiyah Samman in Polman, Syekh. Abdus Shamad had once been picked up forcibly by the troops of DI/TII and brought to the forest of Maros. DI/TII wanted him to teach Islamic instruction and knowledge to Muslim population in the districts controlled by DI/TII and give spiritual instruction to DI/TII army forces. This abduction happened after Syekh. Abdus Samad repeatedly rejected the request of DI/TII asking him to join them. After his abduction, he had no choice but to comply with the request of DI/TII in teaching religion of Islam to the community and the guerrilla forces. The reason behind his abduction was because many of Abdul Qahhar Mudzakkar soldiers were followers of Sheikh Abdus Shamad and his Khalwatiyah tariqah (sufi order). H. Syekh. Muhmud Yusuf, ${ }^{29}$ one of Murshid (spiritual teacher) Tarekat Khalwatiyah Samman in Makassar said that Sheikh Abdus Shamad had many followers in DI/TII army ranks.

The affiliation was grounded by compulsion. After some times he spent in the forest he did not feel any affinity to the DI/TII cause. As a practicing sufi mystic, his activity in the forest beside teaching was performing supplication and meditation. This certainly was different with the outlook of Islam practiced by Abdul Qahhar Mudzakkar and DI/TII personnel who tended to be modernists and orthodox. In short, there was wide gap between the tendency in understanding and applying Islam. This situation was different from the experience of Ag. Abdurrahman Ambo Dalle who at the end were able to make compromises of his ideals although he was a traditionalist Sunni cleric. Sheikh Abdus Shamad did not enjoy living in the forest, though all he needed was supplied by DI/TII. Openly expressing his displeasure and willingness to leave was an impossible thing, because he was prepared to affiliate at the beginning albeit reluctantly. Therefore, he took his own decision to escape the troops tried to retrieve Syekh Abdus Shamad after realizing that the Syekh had been escaped. However, they failed to find him and finally they gave up searching him and return to their position.

\footnotetext{
${ }^{28}$ Syekh Muhammad Ali bin Jaffar, Tarekat Teacher in Khalwatiyah Samman, Interview in Polman in September 2014).

${ }^{29}$ H. Syech Mahmud Yusuf, Mursyid Tarekat Khalwatiyah Samman, Interview in Makassar on October, 2014.
} 


\section{Syekh Abu Bakri bin Fihrin}

Similar with Syekh Abdus Shamad, Syekh Abu Bakri bin Fihrin was subjected to the same treatment. When he was travelling in a village in Minasatene Pangkep Regency, he suddenly met with the troops of DI/TII. The troops directly captured him and took him into forest. It seemed that they had long been planned to have him to join DI/TII of Abdul Qahhar Mudzakkar, and the day they succeed to do it. He specially expected Syekh Abu Bakri bin Fihrin to join the DI/TII band wagon because he was one of Syekh Murshid of Tarekat Khalwatiyah Samman who had many followers. DI/TII expected the affiliation of Tarekat teachers including Syekh Abu Bakri bin Fihrin would attract Tarekat followers to join DI/TII rebellion. However, this expectation did not come to reality. The Tarekat followers were aware of the tactics of guerrilla forces of having their first tarekat spiritual teacher to the forest. They knew that their teacher did not really join DI/TII because of voluntary intention nor religious affinity. Tarekat followers realized that the affiliation of their teacher in DI/TII was not voluntarily. Instead, he was forcibly picked up or was kidnapped.

Starting from the abduction, Syekh Abu Bakri bin Fihrin stayed in the forest along with civilian community and the army forces of DI/TII. After a long waiting, the followers of Tarekat Khalwatiyah did not come to join and support DI/TII. Instead, they requested that Syekh Abu Bakri bin Fihrin to be returned to his village. Since the main reason for the abduction was not eventuate and Syekh Abu Bakri bin Fihrin also refuse to cooperate, DI/TII released him. According to H. Syekh. Mahmud Yusuf, ${ }^{30}$ the DI/TII soldiers escorted him out of the hideout and released him in the location he was abducted.

\section{Syekh Muhammad Sa'id bin Muhammad Yunus}

Syekh Muhammad Sa'id was another teacher of Tarekat Khalwatiyah Samman. He was a disciple of Syekh Abu Bakri bin Fihrin who was given permission to teach Tarekat. When he was in his hostel for pilgrims to Mecca, Sudiang, Makassar, he was abducted by DI/TII and taken into their hideout in the forest. At that time, some of his students and their families who came to the hostel were also caught. In the forest, he was not only asked to teach, but also to work, including farming for the needs of troops.

${ }^{30}$ Ibid. 
Syekh Mahmud Yusef said that Syekh Muhammad Said might be caught when he was in his hostel, he worked in his plantation attached to the hostel. Thus, the DI/TII troops concluded that he was not only a cleric but also able to work physically, such as farming. Therefore, beside teaching Islam, he was also asked to work with the persons who accompany him.

After a long time in forest under a close supervision of the troops, a saturated feeling had started to whack. He expressed his feeling to his followers. He said that if he wanted to leave the forest, he could do that easily. He would just sit in contemplation and close his eyes, then I could go wherever he wanted. However, this situation (the abduction and working for DI/TII) was trials and tribulation from God that he must endure. He could not leave his followers to be tortured by DI/TII troops. He only would leave the forest with his followers. Finally, there was agreement among them to escape from DI/TII hideout and they successfully did so.

Although Syekh Muhammad Sa'id did not occupy the position in the government structure of DI/TII, but since he accepted to join Qahhar, he had done a lot, particularly in developing religious knowledge of the community. The education and missionary endeavor that he performed had given additional knowledge and awareness in enlightening through the life of DI/TII "citizens", including the troops. As a Sufi mystic, the approach he took in carrying out the educational activities and missionary endeavor was certainly an approach of Sufism. Therefore, many DI/TII "citizens" and even the troops of DI/TII later followed his sufi order of Khalwatiyah Samman under his guidance.

\section{Conclusion}

The above information shows that many clerics provided assistance to Abdul Qahhar Mudzakkar and his DI/TII, though some of them affiliated forcibly. Those who gave assistance came from different academic backgrounds with different spectrum of Islam. There were clerics who specialized in Islamic jurisprudence (fiqh), Sufi mystics and combination of both. Among them were given position and there were also given teaching duties both in the formal school with classical system, and in non-formal school with tutorial system or reading Qur'an in the form Assembly tadzkir. The clerics who provided teaching of Sufism, both to the troops and to the public had very great influence. It was proved that after a long time the teachers of 
Sufism of Khalwatiyah sufi order joined them, many disciples within DI/TII were interested in following the sufi order, whereas DI/TII modernist leadership, including Abdul Qahhar Mudzakkar did not seem interested in any form of mysticism.

From the spectrum of Islamic typology, both traditionalist and modernist clerics were present in DI/TII. However, the traditionalists such as Ag. Abdurrahman Ambo Dalle and Syekh Abdus Shamad only joined DI/TII by force. They did not share "ideological identity" with Abdul Qahhar Mudzakkar and DI/TII. Those clerics were educated in traditional sunni boarding schools and practiced sufism. Their recruitment was merely to bolster popular support toward DI/TII. In making them comfortable in DI/TII setting Abdul Qahhar Mudzakkar offered them position within his Islamic state. At least, they were made to teach and provide religious guidance for DI/TII "citizens" and troops. Their advisory role to DI/TII was obeyed as long as it was suitable to opinion of Abdul Qahhar Mudzakkar. If they were contradictory to the aspiration of DI/TII leadership, they would not be heard. Instead, they would be expelled or let to leave DI/TII.

In contrast, the modernists-reformists such as KH. Ma'shum and KH. Ahmad Marzuki Hasan voluntarily joined DI/TII. They supported DI/TII of Abdul Qahhar Mudzakkar with the belief that this DI/TII would serve Islam well. They even believed that DI/TII was the only way to implement Islam in Indonesia. They shared "ideological affinity" with Abdul Qahhar Mudzakkar in many respects. They studied in Muhammadiyah schools and were influenced by its Islamic reformism and modernism agenda. The modernist clerics provided supports, advises, and guidance for DI/TII and directed its course. They were given religious positions in DI/TII structure. They loyally stayed with DI/TII of Abdul Qahhar Mudzakkar until it was permanently suppressed by the central government armed forces in early 1965. []

\section{References}

\section{Books and Articles}

Abady, M. Yusrie. Konsepsi dan Praksis Politik Islam Abdul Qashhar Mudzakear. Unpublished Dissertation, Postgraduate program UIN Syarif Hidayatullah, Jakarta, 2011. 
Ali, Muhammad Daud and Habibah Daud Ali. Lembaga-lembaga Islam di Indonesia. Jakarta: Raja Grafindo Persada, 1995.

Anam, Choirul. Pertumbuhan dan Perkembangan Nabdlatul Ulama. Sala, Jatayu, 1985.

Arief, Syamsuddin. "Dinamika Jaringan Intektual Pesantren di Sulawesi Selatan." Lentera Pendidikan, Vol 11:2, December 2008.

Arif, Gossin. Darah dan Peluru di Desa Tercinta. Makassar: Hasanuddin University Press, 2004.

Bahar, Mattalioe. Petualangan Qahhar Madzakkar. Yogyakarta: Ombak, 2006.

Buehler, Michael. "Elite Competition and Changing State-society Relations: Shari'a Policy Making in Indonesia." Michele Ford and Tom Pepinsky (eds). Beyond Oligarchy: Wealth, Power, and Contemporary Indonesian Politics. Ithaca: Cornell Southeast Asia Program Publications, 2014.

Dokumen Kumpulan Peraturan dan Struktur Organisasi Negara Republik Islam Indonesia DI/TII KPK Penerangan RII Tahun 1957.

Gonggong, Anhar. Abdul Qahhar Mudzakkar: Dari Patriot Hingga Pemberontak. Yogyakarta: Ombak, 2004.

Hamid, Abd. Rahman. Qahhar Mudzakkar di Persimpangan Jalan. Makassar: Pustaka Refleksi, 2008.

Juhannis, Hamdan. The Struggle for Formalist Islam in South Sulawesi: From Darul Islam (DI) to Komite Persiapan Penegakan Syariat Islam (KPPSI). Unpublished dissertation, Canberra: Australian National University, 2006.

Mudzakkar, Abdul Qahhar. Konsepsi Negara Demokrasi Indonesia, Koreksi Pemikiran Politik Pemerintahan Soekarno. Jakarta: Madinah Press, n.d.

Noer, Deliar. Gerakan Modern Islam di Indonesia 1900-1942. Jakarta: LP3ES, 1990.

Piagam Makalua pasal Bab IV tentang Kepartaian dan Aliran Masyarakat Negara, pasal 13 dan 14.

Syamsuddin, A and M. Tahir. Konsepsi Ketuhanan dalam Tarekat Khalwatiyah Samman. Sengkang: n.p., 1997. 
Syukur, Yanuardi, KH. Ahmad Mar₹uki Hasan: Potret Pejuang Syariat Islam, in https:// konstruksipelangi.wordpress.com/2012/06/06/kh-ahmad-marzuki-hasan-potret-pejuang-syariat-islam/ accessed on 12 of August 2014

Tangke, A. Wanuadan Anwar Nasyaruddin, Sejarah Tertembaknya Qabhar Muzakkar di Hutan. Makassar: Pustaka Refleksi, 2007.

Van Dijk, Cornelis. Darul Islam: Sebuah Pemberontakan. Jakarta: Pustaka Utama Grafiti, 1987.

https://www.ifuljihad.blogspot.com/2009/02/KH.-abd-rahman-ambo-dalle.html

https://www.referensimakalah.com.

\section{Interviews}

Hasan, Aswar. Interview. June 2014 in Makassar.

Yusuf, H. Syech Mahmud. Interview. October 2014.

Jaffar, Syekh Muhammad Ali bin. Interview. September 2014 in Polewali Mandar. 